Dicle Tıp Dergisi / Dicle Med J (2019) 46 (1) : 51 - 64

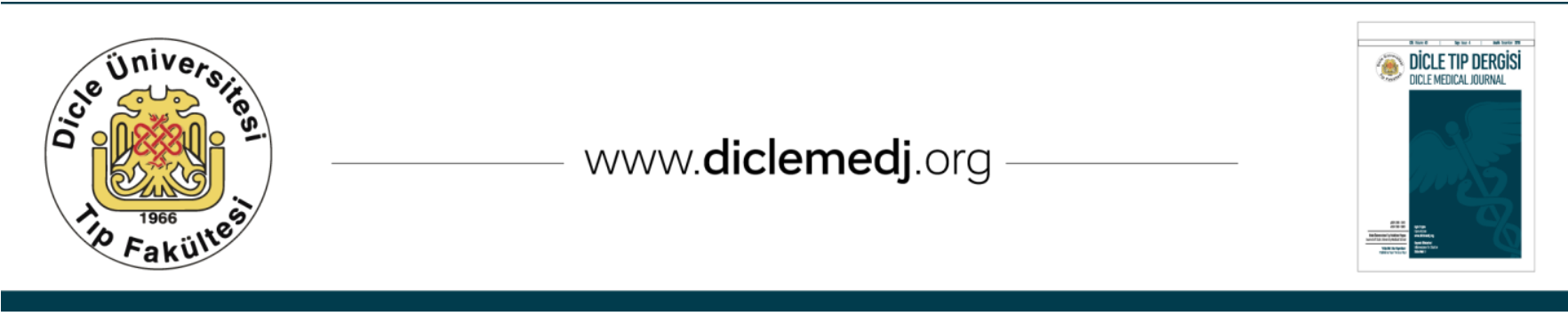

Özgün Araștırma / Original Article

\title{
Methicillin-Resistant Staphylococcus Strains Isolated from Adult Intensive Care Units with E-test MIC Values of Different Antibiotic Research
}

\author{
Narin Gündoğuş¹, Kadri Gül², Tuba Dal³, Nezahat Akpolat \\ 1 Dept of Medical Microbiology, Sancaktepe Sehit Prof. Dr. Ilhan Varank Training and Research Hospital, Istanbul, Turkey ORCID: 0000-0002-1046-8024 \\ 2 Department of Medical Microbiology, Faculty of Medical, Dicle University, Diyarbakır, Turkey, ORCID: 0000-0002-0636-7078 \\ 3 Department of Medical Microbiology, Faculty of Medical, Ankara Yıldırım Beyazit University, Ankara, Turkey ORCID: 0000-0001-7045-1462 \\ 4 Department of Medical Microbiology, Faculty of Medical, Dicle University, Diyarbakır, Turkey, ORCID: 0000-0002-8653-6046
}

\begin{abstract}
Objective: Nasocomial infections are major health problems due to their high morbidity and mortality, prolonged hospital duration and higher treatment costs. Methicillin-resistant staphylococcus species became one of the leading bacteria causing nasocomial infections especially in intensive care units, recently.

The minimum inhibitory concentration value of an antibiotic gives the concentration of antibiotic needed to inhibit the bacteria in the infection area. Careful monitoring of minimal inhibitory concentration (MIC) values is necessary especially during long-term treatments of meticillin-resistant Staphylococcus aureus (MRSA) and meticillin-resistant coagulase-negative staphylococci (MRCoNS) infections $s^{1,2}$. Increasing antibiotic resistance in methicillin-resistant staphylococci, has led to the need for different antibiotics.

Methods: A total of 60 meticillin-resistant staphylococci strains isolated in Microbiology Laboratory of Dicle University Hospital, from clinical specimens of patients in adult İntensive Care Units (ICUs) between April 2013 and March 2014 were included in this study. After identification with conventional and automated system, the antibiotic susceptibility rates of vancomycin, teicoplanin, daptomycin, linezolid, quinupristin/dalfopristin, tigecycline, ceftaroline were determined by E-test method.
\end{abstract}

DOI: $10.5798 /$ dicletip

Yazışma Adresi / Correspondence: Nezahat Akpolat, Department of Medical Microbiology, Dicle University Diyarbakır, Turkey. e-mail: nakpolat21@gmail.com 
Results: The majority of the samples (26.7\%) were sent from Pulmonary Diseases and Tuberculosis intensive care unit and the blood samples were the most common materials (80\%). All staphylococcal strains in our study were determined as susceptible to vancomycin, daptomycin, linezolid, teicoplanin and tigecycline. One (1.6\%) MRCoNS isolate was resistant to quinupristin/dalfopristin while $11(36.6 \%)$ of the MRSA isolates were resistant to ceftaroline. In comparison with the MIC values of MRSA and MRCoNS, only tigecycline was significantly different. Thirty MRSA strains were evaluated in terms of vancomycin-intermediate Staphylococcus aureus/heteroresistant vancomycinintermediate Staphylococcus aureus (VISA/hVISA) with macro E-test method; any VISA/hVISA isolate was not detected.

Antibiotic concentrations below the MIC level, not only leads to treatment failure but also causes mutant bacteria to appear. In order to control the resistance to antibiotics in the treatment of infections due to MRSA and MRCoNS agents, the clinician should be notified of the MIC values of the drugs and the treatment should be planned accordingly.

VISA/hVISA isolates should be considered in treatment failures of infections due to MRSA which are in vitro susceptible to vancomycin. Further testing is needed to detect these isolates.

Despite the fact that ceftaroline is not a drug used in our country, the high resistance rate in our study is remarkable. This situation may be due to the intensive use of other beta-lactam antibiotics. Therefore, antibiotic susceptibility results should be taken into consideration during planning the treatment of infections.

The high average MIC values of tigecycline in MRCoNS infections should also be monitored carefully

Keywords: Methicillin-resistant staphylococci, MIC, E-test, VISA/Hvisa

\section{Erişkin Yoğun Bakım Ünitelerinden İzole Edilen Metisiline Dirençli Staphylococcus Suşlarında E-Test ile Farklı Antibiyotik MİK Değerlerinin Araştırılması}

\section{$\ddot{0} \mathbf{z}$}

Giriş: Hastane enfeksiyonları morbidite ve mortalitesinin yüksek olması, hastanede kalış süresini uzatması ve yüksek tedavi maliyeti nedeniyle önemli bir sağlık sorunudur. Son yıllarda özellikle Yoğun Bakım Ünite (YBÜ)'leri bașta olmak üzere hastane enfeksiyonlarında en sık izole edilen etkenlerin başında metisiline dirençli stafilokok (MRS) türleri gelmektedir. Antibiyotiğin minimum inhibisyon konsantrasyon (MİK) değeri, enfeksiyon bölgesinde bakteriyi inhibe etmek için gereksinim duyulan antibiyotik konsantrasyonudur. Metisilin dirençli Staphylococcus aureus (MRSA) ve Metisilin dirençli Koagulaz Negatif Stafilokok (MRKNS) enfeksiyonlarında, özellikle uzun süreli tedaviler esnasında MİK değerlerinin dikkatle izlenmesi gereklidirr,2. Metisiline dirençli stafilokoklarda gittikçe artan antibiyotik direnci, farklı antibiyotiklere ihtiyaç duyulmasına neden olmuştur.

Yöntemler: Çalışmada Dicle Üniversitesi Hastanesi Mikrobiyoloji Laboratuvarı'na Nisan 2013-Mart 2014 tarihleri arasında erişkin yoğun bakım ünitelerinden gelen metisiline dirençli 60 stafilokok suşu kullanılmıştır. Konvansiyonel ve otomatize sistem ile tür tayini yapıldıktan sonra E-test yöntemi ile vankomisin, teikoplanin, daptomisin, linezolid, kinupristin/dalfopristin, tigesiklin, seftarolin antibiyotiklerine duyarlılıkları araştırılmıștır.

Bulgular: Gögüs Hastalıkları ve Tüberküloz yoğun bakım ünitesi, en fazla örneğin $(\% 26,7)$ gönderildiği klinik, kan örnekleri mikroorganizmaların en sık izole edildiği materyal (\%80) olmuştur. Çalışmamızdaki tüm stafilokok suşları vankomisin, daptomisin, linezolid, teikoplanin ve tigesikline karşı duyarlı bulunmuştur. Bir (\%1,6) MRKNS, kinupristin/dalfopristin'e, $11(\% 36,6)$ MRSA izolatının seftaroline dirençli olduğu bulunmuştur. MRSA ve MRKNS suşlarının MİK değerleri karşılaştırıldığında sadece tigesiklinde anlamlı fark bulunmuştur. Makro E-test yöntemi ile incelenen 30 MRSA suşu içerisinde vankomisine orta duyarlı $S$. aureus/ heterojen vankomisine orta duyarlı S. aureus (VISA/hVISA) suşlar tespit edilmemiştir.

MRSA ve MRKNS suşlarının MİK değerleri karşılaștırıldığında sadece tigesiklinde anlamlı fark bulunmuştur. 30 MRSA suşu, makro E-test yöntemi ile Vankomisine orta duyarlı $S$. aureus/heterojen vankomisine orta duyarlı S. aureus (VISA/hVISA) açısından değerlendirilmiş, VISA/hVISA suşu tespit edilmemiştir.

Antibiyotik MíK değerinin altındaki tedavi dozları, mutant bakterilerin oluşumunda önemli bir faktör olmakla birlikte tedavi başarısızlığına yol açmaktadır. MRSA ve MRKNS etkenlerine bağlı enfeksiyonların tedavisinde antibiyotiklere 
karşı gelişen direncin kontrol altında tutulabilmesi için ilaçların MíK değerlerinin klinisyene bildirilmesi ve buna göre tedavinin planlanması gerekmektedir.

İnvitro olarak vankomisine duyarlı olan ancak tedavi başarısızlığı gösteren MRSA enfeksiyonlarında VISA/hVISA akla gelmeli ve bu yönde ileri tetkikler yapılmalıdır.

Seftarolin, ülkemizde kullanılan bir ilaç olmamasına rağmen çalışmamızda yüksek direnç oranı dikkat çekicidir. Bu durum, diğer beta laktam antibiyotiklerin yoğun kullanımına bağlı olabilir. Dolayısıyla enfeksiyon hastalıklarının tedavisi planlanırken antibiyogram sonuçları mutlaka göz önünde bulundurulmalıdır.

MRKNS enfeksiyonlarında tigesiklindeki ortalama MIK değerinin yüksekliği, izlenmesi gereken bir durumdur.

Anahtar kelimeler: Metisiline dirençli stafilokok, MİK, E-test, VISA/hVISA

\section{INTRODUCTION}

Staphylococcus which belongs to the family of Micrococcaceae is an important genus of bacteria which colonizes the skin and mucosa. Some species of the bacterium can cause different diseases. In recent time a great number of incidents of infection through these bacteria have increasingly been reported in hospitals and among people.

Staphylococcus aureus (S.aureus), the most prominent species of this bacterium, can cause serious infections in tissues and organs. The species other than $S$. aureus are termed as coagulase negative staphylococci (CoNS). While CoNSs were previously accepted only as a normal flora factor, today they have become a disease factor as important as $S$. aureus, causing high rates of mortality and morbidity.

Microorganisms have been developing resistance mechanisms since the discovery of antibiotics. Until recent time, attempts were made to tackle this problem by introducing new antibiotics developed in a continual manner; however we are now observing a period of interruption as far as the development of new antibiotics is concerned. Hence, the majority of the antibiotics developed in the last decade have been produced by modifying the existing ones.

Thanks to penicillin which was released for clinical usage at the beginning of 1940s years, the number of infections developed in association with $S$. aureus showed a dramatic decline. But it was observed, after a while, that certain bacteria began to produce penicillinase to develop resistance to antibiotics. In the years that follow, the number of isolates that produced $\beta$-lactamase gradually increased, reaching today a level of 95 per cent. Coagulase negative staphylococci (CoNS) entered the picture as an important pathogen in respect of infections emerging in hospitals. Of the CoNS isolates in connection with hospital infections, 80-90 per cent is coagulase negative staphylococci that are resistant to methicillin.

The staphylococci resistant to methicillin are also resistant to $\beta$-lactamases. For this reason, there arise, in the treatment of diseases caused by these bacteria, the need to use other antibiotics which can be applied as alternative to glycopeptides.

The present study conducted in our hospital sought to determine the current and reliable drug resistance (vancomycin, teicoplanin, daptomycin, linezolid , tigecycline, quinupristin/dalfopristin, ceftaroline) of the staphylococcus strains resistant to methicillin, to contribute to the treatment of infections with high morbidity and mortality with appropriate antibiotics in the early period and thus to reduce the morbidity and mortality rates and to prevent higher healthcare costs arising from longer hospitalization due to unnecessary usage of antibiotics and consequent delays in the recovery of patients. 


\section{METHOD}

\section{Isolation from Clinical Samples}

In our study, 60 strains in total, being methicillin-resistant Staphylococcus aureus (MRSA) and methicillin-resistant coagulase negative staphylococci (MRCoNS), sent to the Microbiology and Clinical Microbiology Laboratory of the Medicine Faculty of Dicle University from adult intensive care units between April 2013 and March 2014 were selected through random sampling procedure. When more than one sample was taken from the same patient, only one of them was included in the study. The contaminated samples were excluded from the study.

\section{Identification and Assessment}

First of all, Gram staining was applied on the suspected staphylococcus colonies grown on the culture samples sent to the laboratory. Groups were formed during the Gram staining process, and catalase and tube coagulase tests were applied to the gram-positive cocci. After the catalase and coagulase procedures, the strains were given to the automated system PhoenixTM 100 (Becton-Dickinson, USA), a system routinely used for identification and sensitivity. All the staphylococcus strains were controlled as to whether or not they were methicillin-resistant. Dehydrated Mueller Hinton Agar (BBL) was prepared in accordance with the instructions of the producer company. The agar plates were stored in the refrigerator under a temperature of 2-8 $0 \mathrm{C}$ after they got hardened in room temperature. When each medium was prepared, agar plates in a number to represent the prepared plates were incubated $18 \pm 2$ hours at $35 \pm 1^{\circ} \mathrm{C}$ and controlled in respect of sterility. These processes were implemented one day before each procedure, using a fresh medium each time. Suspensions in McFarland 0.5 turbidity were prepared from the 24-hour cultures of the staphylococcus to be examined in triptych soy medium, and cultivation was made from the suspension to Mueller-Hinton agar.

Standard cefoxitin disks of $30 \mu \mathrm{g}$ (Oxoid, England) were used to determine the methicillin resistance. Inhibition zones were measured after a 20-hours incubation under 35 ${ }^{\circ} \mathrm{C}$ and were assessed under European Committee on Antimicrobial Susceptibility Testing (EUCAST) criteria ${ }^{3}$. For $S$. aureus, $S$. lugdunensis, $S$. saprophyticus, those with a cefoxitin zone diameter of $\geq 22$ were accepted as sensitive, and those with $22 \leq$ as resistant. For CoNS (Except for $S$. lugdunensis and $S$. saprophyticus) those having $\geq 25$ were accepted as susceptible and those with $\leq 25$ as resistant. ATCC 29213 S. aureus was used as a control strain. The strains obtained were stored in a bouillon with 16 per cent glycerol under $-80^{\circ} \mathrm{C}$ until they were processed.

\section{Antibacterial Phenotypic E-Test Method}

The resistance susceptibility of staphylococci to different antibiotics was measured in MuellerHinton agar, taking thereby account of the EUCAST. Inoculum was prepared as defined in the disk diffusion method.

Inert plastic strips of vancomycin 0.016-256 (Biomerieux, France), teicoplanin 0.016-256 (Biomerieux, France), daptomycin 0.016-256 (Biomerieux, France), linezolid 0.016-256 (Biomerieux, France), tigecycline 0.015-256 (Oxoid, England), quinupristin/dalfopristin 0.002-32 (Biomerieux, France), ceftaroline 0.002-32 (Biomerieux, France) in everincreasing concentrations were placed in the medium of Mueller-Hinton agar.

MIC value of each antibiotic was determined by incubating the plates for 18-20 hours under 35 0C. In E-test evaluation, the MIC value, if any among the values, at the point where the breeding intersects with the strip was read.

In the presence of a sharp border, the point where the breeding intercepted with the strip, on the other hand, in the absence of a sharp 
border, the data being taken account were the values that indicated the inhibition of 90 per cent for linezolid, 80 per cent for tigecycline and 100 per cent for other antibiotics. Evaluations were made by two different people using double-blind method.

\section{Macro E-test Method}

$100 \mu \mathrm{l}$ was taken from bacterium suspensions fixed at 2 McFarland turbidity and was spread over the surface of $90 \mathrm{~mm}$ BHI agar medium in the modus as defined by Wootton et all.4. Vancomycin (0.016-256 $\mu \mathrm{g} / \mathrm{ml})$ and teicoplanin (0.016-256 $\mu \mathrm{g} / \mathrm{ml})$ E-test strips were placed and incubated for 24 and 28 hours under $35^{\circ} \mathrm{C}$. In interpreting the results, the isolates with vancomycin and teicoplanin MIC values of $\geq 8$ $\mu \mathrm{g} / \mathrm{ml}$ or those isolates with a teicoplanin MIC value of only $\geq 12 \mu \mathrm{g} / \mathrm{ml}$ were interpreted to be VISA/hVISA (Figure 1).



Figure 1: Macro E-test method

\section{Statistic Method}

Student-t test was used in comparing the resistance rates of MSSA and MRSA strains to antibiotic and statistical significance level was accepted as $\mathrm{p}<0.05$.

\section{RESULTS}

The Intensive Care Unit (ICU) which provided the materials where the bacteria groups were isolated are shown at Table 1 . The emergency unit of chest diseases TB which provided 16 samples $(26.7 \%)$ was the clinic which provided the most samples.

With 40 (80\%) samples, blood was the sample in which the majority of the microorganisms were isolated among the samples where bacterium groups were isolated. Other materials were mucus (3 samples), catheter (3 samples), wound wipe sample (3 samples) and pleura, tracheal, aspirate and drain fluid (each with 1 sample) (Table2).

In the bacteria isolated, the majority of the blood samples, i.e. 14 samples out of 48 $(23.3 \%)$ were provided by the intensive care unit of Chest Diseases TB. Table 3 shows the antibiotics MIC $(\mu \mathrm{g} / \mathrm{ml})$ of isolates and microorganisms.

Table 4 shows the MIC50 $(\mu \mathrm{g} / \mathrm{ml})$ and MIC90 $(\mu \mathrm{g} / \mathrm{ml})$ values as well as MIC interval $(\mu \mathrm{g} / \mathrm{ml})$ of microorganisms.

Table 5 shows MIC $(\mu \mathrm{g} / \mathrm{ml})$ average values in MRSA and MRCoNS strains.

Reviewing the MRSA and MRCoNS strains in respect of antibiotics MIC $(\mu \mathrm{g} / \mathrm{ml})$ average values, a significant difference in tigecycline was found.

Table 6 shows vancomycin and teicoplanin MIC $(\mu \mathrm{g} / \mathrm{ml})$ values of MRSA strains after 24 and 48 hours in agar.

No VISA/hVISA was detected at 30 MRSA strains. 
Table 1: Intensive Care Unit which provided the bacteria groups

\begin{tabular}{|c|c|c|c|c|c|c|c|c|c|c|c|c|}
\hline \multirow{3}{*}{ ICU } & \multicolumn{12}{|c|}{ Sample } \\
\hline & \multicolumn{2}{|c|}{ blood } & \multicolumn{2}{|c|}{ mucus } & \multicolumn{2}{|c|}{ catheter } & \multicolumn{2}{|c|}{ Wound } & \multicolumn{2}{|c|}{ outher } & \multicolumn{2}{|c|}{ total } \\
\hline & $\mathbf{n}$ & $\%$ & $\mathbf{n}$ & $\%$ & $\mathbf{n}$ & $\%$ & $\mathbf{n}$ & $\%$ & $\mathbf{n}$ & $\%$ & $\mathbf{n}$ & $\%$ \\
\hline Chest Diseases T.B.C & \multicolumn{2}{|c|}{1429.2} & \multicolumn{2}{|c|}{133.3} & \multicolumn{2}{|c|}{133.3} & \multicolumn{2}{|c|}{-} & \multicolumn{2}{|c|}{-} & \multicolumn{2}{|c|}{1626.7} \\
\hline Anesthesia & \multicolumn{2}{|c|}{612.5} & \multicolumn{2}{|c|}{ - } & \multicolumn{2}{|c|}{133.3} & \multicolumn{2}{|c|}{-} & \multicolumn{2}{|c|}{-} & \multicolumn{2}{|c|}{711.7} \\
\hline Cardiology & \multicolumn{2}{|c|}{48.3} & \multicolumn{2}{|c|}{-} & \multicolumn{2}{|c|}{ - } & \multicolumn{2}{|c|}{133.3} & \multicolumn{2}{|c|}{ - } & \multicolumn{2}{|c|}{58.4} \\
\hline Neurology & \multicolumn{2}{|c|}{1123} & \multicolumn{2}{|c|}{133.3} & \multicolumn{2}{|c|}{133.3} & \multicolumn{2}{|c|}{-} & \multicolumn{2}{|c|}{133.3} & \multicolumn{2}{|c|}{1423.3} \\
\hline General Surgery & \multicolumn{2}{|c|}{24.2} & \multicolumn{2}{|c|}{-} & \multicolumn{2}{|c|}{-} & & & & & & \\
\hline Chest Surgery & & & & & & & & & & & & \\
\hline Neurosurgery & & & & & & & & & & & & \\
\hline Internal Diseases & & & & & & & & & & & & \\
\hline Orthopedics & & & & & & & & & & & & \\
\hline Nephrology & & & & & & & & & & & & \\
\hline Cardiovascular Disorders & & & & & & & & & & & & \\
\hline Total & & & & & & & & & & & & \\
\hline
\end{tabular}

\section{DISCUSSION}

For the clinician, the MIC value of an antibiotic refers to the value of antibiotic concentration needed to inhibit the bacteria in the infected area. In the emergency care units where antibiotics are used in extreme amounts, a careful monitoring of MIC values in infections caused by MRSA and MRCoNS contributes to a successful treatment.

The detection of VISA and hVISA isolates is very problematic. The disc diffusion method and automated systems, methods frequently used in laboratories, remain incapable in respect of detecting the isolates ${ }^{5}$.

Nowadays it is suggested that vancomycin, teicoplanin, tigecycline, linezolid ve daptomycin can be used as useful and effective alternatives in the treatment of bacterial infections resistant to many drugs ${ }^{2}$.

An increase in resistance of MRSA and MRCoNS strains, especially the emergence of resistance in glycopeptides which were expected to show no resistance until recent time (reports about strains with reduced susceptibility or resistance to vancomycin first in Japan and the USA and later in some other countries) indicated the need for new antibiotics ${ }^{6}$.

Table 2: Materials included in the study
\begin{tabular}{|l|c|c|}
\hline Specimen & $\mathrm{n}$ & $\%$ \\
\hline Blood & 48 & 80 \\
\hline Pleura & 1 & 1.7 \\
\hline Drain fluid & 1 & 1.7 \\
\hline Mucus & 3 & 5 \\
\hline Catheter & 3 & 5 \\
\hline Wound & 3 & 5 \\
\hline Tracheal aspirate culture & 1 & 1.6 \\
\hline Total & 60 & 100 \\
\hline
\end{tabular}

Hal et all. ${ }^{7}$ suggested that vancomycin is the basic drug to be used for the treatment of MRSA, and that, however, high MIC values have led to concerns about the effectiveness of the drug. 
Table 3: MIC values $(\mu \mathrm{g} / \mathrm{ml})$ of isolates and antibiotics

\begin{tabular}{|c|c|c|c|c|c|c|c|}
\hline Factor & VA & DPC & $\mathbf{L Z}$ & TP & TGC & CPT & QDA \\
\hline S. epidermidis & 1.5 & 0.094 & 0.75 & 2 & 0.25 & 3 & 1 \\
\hline S. hominis & 2 & 0.5 & 0.75 & 2 & 0.5 & 0.25 & 0.5 \\
\hline S. hominis & 2 & 0.094 & 0.75 & 1.5 & 0.12 & 1.5 & 0.5 \\
\hline S. hominis & 1 & 0.125 & 0.5 & 0.38 & 0.06 & 0.25 & 0.75 \\
\hline S. epidermidis & 1.5 & 0.094 & 1.5 & 2 & 0.25 & 0.75 & 0.75 \\
\hline S. aureus & 1.5 & 0.125 & 1 & 2 & 0.12 & 1.5 & 1 \\
\hline S. aureus & 2 & 0.094 & 1.5 & 1 & 0.12 & 0.75 & 1 \\
\hline S. epidermidis & 1 & 0.094 & 0.75 & 2 & 0.5 & 0.75 & 0.75 \\
\hline S. aureus & 0.75 & 0.094 & 1 & 0.5 & 0.12 & 0.5 & 0.5 \\
\hline S. epidermidis & 1.5 & 0.064 & 1 & 0.125 & 0.5 & 1 & 1 \\
\hline S. haemolyticus & 1 & 0.032 & 0.5 & 2 & 0.5 & 1.5 & 1 \\
\hline S. aureus & 1.5 & 0.5 & 0.75 & 1.5 & 0.06 & 0.38 & 0.75 \\
\hline S. aureus & 1.5 & 0.25 & 2 & 0.5 & 0.12 & 0.75 & 1 \\
\hline S. aureus & 0.75 & 0.094 & 0.75 & 0.19 & 0.12 & 1 & 1 \\
\hline S. aureus & 1 & 0.125 & 1 & 1 & 0.25 & 0.75 & 1 \\
\hline S. aureus & 1 & 0.19 & 1.5 & 0.75 & 0.12 & 0.5 & 1 \\
\hline S. aureus & 2 & 0.5 & 0.5 & 2 & 0.12 & 0.38 & 1 \\
\hline S. epidermidis & 3 & 0.75 & 1 & 2 & 0.25 & 1 & 1 \\
\hline S. epidermidis & 1 & 0.125 & 1.5 & 0.19 & 0.5 & 1 & 0.5 \\
\hline S. aureus & 1 & 0.094 & 1 & 0.19 & 0.5 & 1 & 0.75 \\
\hline S. aureus & 1.5 & 0.19 & 1.5 & 2 & 0.12 & 2 & 1 \\
\hline S. epidermidis & 1 & 0.094 & 0.75 & 0.19 & 0.5 & 2 & 1 \\
\hline S. saprophyticus & 1.5 & 0.19 & 0.75 & 1.5 & 0.12 & 0.38 & 0.75 \\
\hline S. epidermidis & 0.5 & 0.064 & 1.5 & 0.125 & 0.25 & 0.25 & 1 \\
\hline S. aureus & 2 & 0.094 & 1.5 & 1.5 & 0.12 & 1 & 1 \\
\hline S. epidermidis & 3 & 0.5 & 0.5 & 3 & 0.12 & 0.38 & 0.5 \\
\hline S. haemolyticus & 1.5 & 0.094 & 0.75 & 2 & 0.25 & 3 & 1 \\
\hline S. aureus & 1 & 0.125 & 1 & 1 & 0.25 & 0.75 & 0.75 \\
\hline S. epidermidis & 3 & 0.25 & 0.75 & 3 & 0.12 & 2 & 1 \\
\hline S. epidermidis & 1.5 & 0.19 & 0.75 & 3 & 0.5 & 0.38 & 0.38 \\
\hline S. sciuri & 1.5 & 1 & 3 & 3 & 0.12 & 1.5 & 4 \\
\hline S. epidermidis & 1 & 0.094 & 0.75 & 0.125 & 0.5 & 2 & 0.75 \\
\hline S. aureus & 1 & 0.25 & 1.5 & 0.38 & 0.5 & 1 & 0.75 \\
\hline S. aureus & 2 & 0.19 & 1 & 2 & 0.5 & 3 & 0.75 \\
\hline S. aureus & 1.5 & 0.19 & 1 & 2 & 0.06 & 3 & 0.75 \\
\hline S. aureus & 0.75 & 0.125 & 1 & 0.38 & 0.12 & 0.38 & 0.5 \\
\hline S. aureus & 1.5 & 0.19 & 1.5 & 0.75 & 0.25 & 0.75 & 0.75 \\
\hline S. aureus & 1 & 0.19 & 1 & 0.75 & 0.12 & 2 & 1 \\
\hline S. haemolyticus & 2 & 0.094 & 1 & 2 & 0.25 & 3 & 1 \\
\hline S. aureus & 2 & 0.5 & 0.5 & 2 & 0.12 & 0.75 & 0.75 \\
\hline S. aureus & 1.5 & 0.19 & 1 & 1.5 & 0.25 & 1 & 1 \\
\hline S. capitis & 1.5 & 0.75 & 1 & 1.5 & 0.25 & 3 & 1 \\
\hline S. epidermidis & 2 & 0.19 & 0.38 & 2 & 0.25 & 0.5 & 1 \\
\hline S. epidermidis & 3 & 0.19 & 0.5 & 1.5 & 0.06 & 0.5 & 0.75 \\
\hline S. aureus & 1.5 & 1 & 1 & 1 & 0.25 & 1 & 0.5 \\
\hline S. epidermidis & 1 & 0.064 & 0.5 & 0.19 & 0.12 & 1 & 1 \\
\hline S. aureus & 1.5 & 0.19 & 1 & 1 & 0.12 & 1.5 & 1 \\
\hline S. aureus & 1 & 0.19 & 0.5 & 0.75 & 0.12 & 0.75 & 1 \\
\hline S. haemolyticus & 2 & 0.064 & 0.75 & 2 & 0.25 & 6 & 0.5 \\
\hline S. aureus & 2 & 0.19 & 1 & 1.5 & 0.12 & 2 & 1 \\
\hline S. aureus & 2 & 0.25 & 1.5 & 2 & 0.25 & 3 & 1 \\
\hline S. aureus & 1.5 & 0.25 & 0.75 & 1.5 & 0.25 & 2 & 1 \\
\hline S. epidermidis & 2 & 0.5 & 1 & 2 & 0.5 & 4 & 0.5 \\
\hline S. epidermidis & 2 & 0.38 & 0.5 & 2 & 0.5 & 0.38 & 0.75 \\
\hline S. epidermidis & 2 & 0.25 & 0.5 & 2 & 0.12 & 0.5 & 1 \\
\hline S. epidermidis & 1.5 & 0.19 & 1 & 0.38 & 0.12 & 6 & 0.75 \\
\hline S. aureus & 1 & 0.25 & 1.5 & 1.5 & 0.12 & 1 & 1 \\
\hline S. aureus & 2 & 0.19 & 1 & 1 & 0.25 & 2 & 0.75 \\
\hline S. epidermidis & 2 & 0.19 & 0.5 & 1.5 & 0.5 & 3 & 1 \\
\hline S. aureus & 1.5 & 0.064 & 0.75 & 1.5 & 0.25 & 2 & 1 \\
\hline
\end{tabular}

Prakash et all. ${ }^{8}$ reported that treatment in MRSA infections turned out to unsuccessful in spite of a MIC value of $\leq 2 \mu \mathrm{g} / \mathrm{ml}$ for susceptibility to vancomycin, as a result of which concerns were raised in recent studies over the role of vancomycin in treatment. Another study found a clinical response in a rate of 62 per cent in infections caused by MRSAs with a MIC value of $\geq 2 \mu \mathrm{g} / \mathrm{ml}$ and that in a rate of 85 per cent caused by those with a MIC value of $<2 \mu \mathrm{g} / \mathrm{ml}^{9}$.

Table 4: MIC50 and MIC90 values of microorganisms and MIC interval

\begin{tabular}{|l|c|c|c|}
\hline Antibiotics & $\begin{array}{c}\text { MIC50 } \\
(\boldsymbol{\mu g} / \mathbf{m L})\end{array}$ & $\begin{array}{c}\text { MIC } \\
(\boldsymbol{\mu g} / \mathbf{m L})\end{array}$ & $\begin{array}{c}\text { MIC } \\
\text { Interval } \\
(\boldsymbol{\mu g} / \mathbf{m L})\end{array}$ \\
\hline Vancomycin & 1.5 & 2 & $0.75-3$ \\
MRSA & 1.5 & 3 & $0.5-3$ \\
MRCoNS & 0.19 & 0.5 & $0.064-1$ \\
\hline Daptomycin & 0.125 & 0.5 & $0.032-1$ \\
MRSA & & & \\
MRCoNS & 1 & 1.5 & $0.5-2$ \\
\hline Linezolid & 0.75 & 1.5 & $0.38-3$ \\
MRSA & 1 & 2 & $0.19-2$ \\
MRCoNS & 2 & 3 & $0.125-3$ \\
\hline Teicoplanin & & & \\
MRSA & 0.12 & 0.25 & $0.06-0.5$ \\
MRCoNS & 0.25 & 0.5 & $0.06-0.5$ \\
\hline Tigecycline & & & \\
MRSA & 1 & 2 & $0.38-3$ \\
MRCoNS & 1 & 3 & $0.25-6$ \\
\hline Ceftaroline & 1 & 1 & $0.5-1$ \\
MRSA & 0.75 & 1 & $0.38-4$ \\
\hline MRCoNS & & & \\
\hline Quinupristin/Dalfopristin & & & \\
MRSA & & & \\
MRCoNS & & & \\
\hline
\end{tabular}

Korten $\mathrm{V} 10$ reports that there has been an increase in vancomycin MIC values in MRSA infections in the past few years in many countries in the world, including our country where such an increase has also been detected in recent time, with vancomycin MIC values of over $1 \mathrm{mg} / \mathrm{L}$ in 40 per cent of isolates. Our study found a vancomycin MIC value of over 1 $\mathrm{mg} / \mathrm{L}$ in 63 per cent $(\mathrm{n}=19)$ of MRSAs. We are of the opinion that the high value found in our study could be ascribed to the high degree of vancomycin usage in our hospital. 
Table 5: MIC ( $\mu \mathrm{g} / \mathrm{ml})$ average values in MRSA and MRCoNS strains

\begin{tabular}{|c|c|c|}
\hline Antibiotics & \begin{tabular}{|c|} 
Average \\
Value
\end{tabular} & $\mathbf{P}^{*}$ \\
\hline $\begin{array}{l}\text { Vancomycin } \\
\text { MRSA } \\
\text { MRCoNS } \\
\end{array}$ & $\begin{array}{l}1,425 \\
1,700\end{array}$ & 0.053 \\
\hline $\begin{array}{l}\text { Daptomycin } \\
\text { MRSA } \\
\text { MRCoNS } \\
\end{array}$ & $\begin{array}{l}0.2291 \\
0,2437\end{array}$ & 0.79 \\
\hline \begin{tabular}{|l|} 
Linezolid \\
MRSA \\
MRCoNS \\
\end{tabular} & $\begin{array}{l}1,08 \\
0,87 \\
\end{array}$ & 0.06 \\
\hline $\begin{array}{l}\text { Teicoplanin } \\
\text { MRSA } \\
\text { MRCoNS } \\
\end{array}$ & $\begin{array}{l}1,19 \\
1,57 \\
\end{array}$ & 0.06 \\
\hline $\begin{array}{l}\text { Tigecycline } \\
\text { MRSA } \\
\text { MRCoNS } \\
\end{array}$ & $\begin{array}{l}0,1930 \\
0,2943\end{array}$ & 0.001 \\
\hline $\begin{array}{l}\text { Ceftaroline } \\
\text { MRSA } \\
\text { MRCoNS } \\
\end{array}$ & $\begin{array}{l}1,280 \\
1,692 \\
\end{array}$ & 0.20 \\
\hline $\begin{array}{l}\text { Quinupristin/Dalfopristin } \\
\text { MRSA } \\
\text { MRCoNS }\end{array}$ & $\begin{array}{l}0,88 \\
0,95\end{array}$ & 0.56 \\
\hline
\end{tabular}

Many studies conducted in our country also found results indicating, similar to our study, vancomycin-resistant strains ${ }^{11,12}$. It was reported that the rate of staphylococci nonresistant to vancomycin, but with reduced susceptibility to it amounted to 0.9-17.9 per cent $^{13}$.

Similar to the results we have obtained in our study, Elsahn et all. ${ }^{14}$ also showed that both MRSA and MRCoNS isolates were susceptible to vancomycin and linezolid. Another study executed in our country similarly found that MRSA strains had no resistance to vancomycin and linezolid 15 .
Table 6: Vancomycin and Teicoplanin MIC $(\mu \mathrm{g} / \mathrm{ml})$ values of MRSA strains after 24 and 48 hours in BHI agar.

\begin{tabular}{|c|c|c|}
\hline NO & VA/TP after 24 hours & VA/TP after 48-hours \\
\hline 2631 & $2 / 2$ & $2 / 2$ \\
\hline 2513 & $4 / 6$ & $6 / 8$ \\
\hline 2642 & $2 / 3$ & $2 / 3$ \\
\hline 2572 & $4 / 6$ & $4 / 6$ \\
\hline 2496 & $6 / 6$ & $6 / 8$ \\
\hline 2502 & $3 / 4$ & $3 / 6$ \\
\hline 2514 & $1.5 / 2$ & $1.5 / 3$ \\
\hline 2576 & $1 / 0.38$ & $1 / 1$ \\
\hline 2632 & $1 / 0.75$ & $1 / 1$ \\
\hline 2221 & $3 / 3$ & $3 / 4$ \\
\hline 2581 & $2 / 2$ & $2 / 3$ \\
\hline 2627 & $1 / 0.25$ & $1.5 / 0.25$ \\
\hline 2616 & $2 / 2$ & $2 / 3$ \\
\hline 2624 & $1.5 / 1$ & $2 / 1.5$ \\
\hline 2494 & $1.5 / 1$ & $1.5 / 1.5$ \\
\hline 2498 & $2 / 1.5$ & $3 / 2$ \\
\hline 2626 & $1.5 / 0.25$ & $2 / 0.38$ \\
\hline 2622 & $1.5 / 1.5$ & $2 / 3$ \\
\hline 2263 & $1 / 2$ & $1.5 / 2$ \\
\hline 2645 & $2 / 1$ & $2 / 1.5$ \\
\hline 2621 & $2 / 3$ & $2 / 4$ \\
\hline 2615 & $2 / 2$ & $2 / 3$ \\
\hline 2579 & $2 / 1$ & $2 / 2$ \\
\hline 2646 & $2 / 3$ & $3 / 4$ \\
\hline 2637 & $1.5 / 6$ & $1.5 / 8$ \\
\hline 2495 & $1 / 2$ & $1 / 2$ \\
\hline 2613 & $1.5 / 2$ & $2 / 2$ \\
\hline 2617 & $2 / 1.5$ & $2 / 1.5$ \\
\hline 2614 & $2 / 2$ & $2 / 3$ \\
\hline 2244 & $3 / 6$ & $3 / 6$ \\
\hline
\end{tabular}

Doğan et all. ${ }^{16}$ found that $S$. aureus isolates, which had demonstrated no resistance to vancomycin and teicoplanin antibiotics 
between January 2001 and December 2002, developed a resistance to these antibiotics in a rate of 1.7 per cent in the period between January 2011 and December 2012. According to Yanık et all. ${ }^{17}$, while results obtained in different years indicated that vancomycin MIC values in connection with MRSA infections showed a decline, there occurred an increase in values in connection with infections caused by MRCoNS. The same study obtained results that indicated no resistance to vancomycin, teicoplanin and linezolid in Turkey.

It has been reported that the broad usage of vancomycin in MRSA infections causes an increase of MIC values in vancomycinsusceptible strains in many countries. After the staphylococcus strain showing a resistance of medium level to vancomycin, the first such case reported in Japan in 1997, staphylococcus strains resistant to glycopeptides have become a source of great concern ${ }^{13}$.

Of 148 staphylococcus isolates resistant to methicillin, Kuşcu et all. ${ }^{18}$ defined 5 (3.4\%) as VIS and $2(1.4 \%)$ as hVISA. Taking account of S.aureus strains, on the other hand, they similarly found a VISA (1/107) and hVISA (1/107) prevalence of 0.9 per cent. We have found no VISA/hVISA resistance in our study. We think that such a result can be ascribed to different methods and differing number of samples we used.

Research has reported that hVISA incidence in MRSA isolates especially with a vancomycin MIC value of 2 was higher in 2011 compared to $2009^{19}$.

Çelikbilek et all. ${ }^{20}$ measured MIC 50 and MIC 90 values in MRSA isolates and reported that they turned out to be 0.75 and $1.5 \mu \mathrm{g} / \mathrm{ml}$ for vancomycin, 2 and $3 \mu \mathrm{g} / \mathrm{ml}$ for teicoplanin, 0.38 and $0.5 \mu \mathrm{g} / \mathrm{ml}$ for linezolid and 0.094 and 0.19 $\mu \mathrm{g} / \mathrm{ml}$ for daptomycin. While our study found higher MIC50 and MIC90 values of MRSA for vancomycin, linezolid and daptomycin, lower values for teicoplanin came into the picture.
Teicoplanin is an antimicrobial agent more preferred in the pediatric emergency care unit in our hospital. This lower MIC value in teicoplanin might be attributed to our patient profile consisting of patients who are treated in emergency care unit for adults in our hospital.

Aktaş et all. ${ }^{22}$ found MIC50 and MIC90 values in MRSA isolates as $0.12 \mu \mathrm{g} / \mathrm{ml}$ and $0.5 \mu \mathrm{g} / \mathrm{ml}$ respectively and the MIC interval as $\leq 0.032-1$ $\mu \mathrm{g} / \mathrm{ml}^{21}$. In another study conducted in our country, researchers found no resistance to daptomycin in MRSA and MRCoNS strains. Daptomycin MIC values for both MRSA and MRCoNS strains were found to be MIC50 0.125 and MIC90 0.25. We also found no resistance to daptomycin in staphylococcus strains we similarly processed.

Sader et all. ${ }^{23}$ reported that daptomycin and linezolid were drugs alternative to vancomycin, but that there has also been, at the same time, an increasing decline in susceptibility in these drugs. They pointed out in the same study that ceftaroline in MIC90 $1 \mu \mathrm{g} / \mathrm{ml}$ showed an invitro effectiveness both against gram-positive and gram-negative bacteria including MRSA with reduced vancomycin susceptibility and with a strong activity in MRSA infections resistant to daptomycin and linezolid. It was also suggested that ceftaroline continued to have efficiency against $S$. aureus resistant to daptomycin, $S$. aureus resistant to vancomycin and against MRSAs with reduced susceptibility to vancomycin that comprise daptomycin and hVISA ${ }^{24}$.

Clinical studies have brought evidence about the effectiveness of linezolid in MRSA treatment, and it is reported that it can lead to better results in the treatment of complicated skin and soft tissue infections caused by MRSAs. Even though some studies have indicated a resistance of MRSA strains to linezolid, this resistance has so far posed no clinical problem. It is argued, thanks to its 
characteristic of inhibiting toxin production, that it can be the optimal option in the treatment of MRSA infections ${ }^{25}$.

A study conducted in our country on 516 staphylococcus strains, being 321 MRSA and 195 MSSA, found no resistance to linezolid 26.

Another study which investigated the in-vitro effectiveness of linezolid found that all the MRSA strains were susceptible to this antibiotic. The same study demonstrated that all the isolates had a MIC interval of 0.023-0.75 $\mathrm{mg} / \mathrm{dl}$, whereby MIC50 and MIC90 were found to be $0.25 \mathrm{mg} / \mathrm{dl}$ and $0.5 \mathrm{mg} / \mathrm{dl}$ respectively ${ }^{27}$. It was reported in another study executed in our country by Al et all. that all of the $63 \mathrm{MRSA}$ strains were susceptible to linezolid and quinupristin/dalfopristin ${ }^{28}$. Even though Yanık et all. ${ }^{17}$ argued that linezolid resistance was not widely prevalent in MRSA and MRCoNS isolates, their observations in some other studies indicated an increase in the MIC value of linezolid.

Ağalar et all. ${ }^{30}$ found no resistance of MRSAs and MRCoNSs to linezolid; besides, previous research executed at home also demonstrated that methicillin-resistant staphylococcus strains developed no resistance to linezolid ${ }^{29}$. In another study conducted in our country, linezolid MIC50 and MIC90 values were found to be $1.5 \mu \mathrm{g} / \mathrm{mL}$ and $2 \mu \mathrm{g} / \mathrm{mL}$ at MRSA respectively.

Doğanay et all. ${ }^{11}$ documented that $S$. aureus and CoNS strains had no resistance to vancomycin, teicoplanin and quinupristin/dalfopristin. Öksüz et all. ${ }^{6}$, on the other hand, found that both MRSA and MRCoNS strains were not resistant to quinupristin/dalfopristin. In the same study, they documented MIC50 and MIC90 values for quinupristin/dalfopristin as 0.50 and $0.75 \mu \mathrm{g} / \mathrm{ml}$ for MRSA and as $0.75 \mathrm{ve}$ $0.50 \mu \mathrm{g} / \mathrm{ml}$ for MRCoNS respectively. In our study, MIC50 and MIC90 values were found to be 1 and $1 \mu \mathrm{g} / \mathrm{ml}$ for MRSA and 0.75 and 1 $\mu \mathrm{g} / \mathrm{ml}$ for MRCoNS respectively.
Yavuz et all., who conducted a study to investigate the susceptibility of 200 staphylococcus strains, being 100 MRSAs and 100 MSSAs, to vancomycin and quinupristin/dalfopristin, found no resistance to vancomycin, but a MRSA strain obtained from a conjunctival wipe sample was resistant to quinupristin/dalfopristin ${ }^{12}$.

Kali A et all. ${ }^{31}$ reported that even though the resistance of MRSA strains to quinupristin/dalfopristin was found to be at a relatively unimportant level (0-0.3\%) in Europe, North and Latin America in the last decade, a level of 31 per cent was documented in Taiwan, a notably high level in a country where the drug is not used in clinical practices. In the same study, they also documented a high resistance level of 87 per cent in North India where the drug is not used in clinical practices as well. In a study they themselves conducted in South India, they documented that while 10 of 102 strains were susceptible at medium level and 92 were found to be susceptible, no strains were found to be resistant. They observed the MIC interval of susceptible strains as $0.125-0.5$ $\mathrm{mg} / \mathrm{l}$.

The resistance mechanisms of quinupristin/dalfopristin might be associated, on the one hand, with the mutation in the ribosome; but on the other hand it might also be related to enzymes and active efflux systems which can activate the antibiotic, as is the case with staphylococcus species ${ }^{32}$. We found that 1 MRCoNS strain (1.6\%) was resistant to quinupristin/dalfopristin. The existence of resistance in the strain, which was bred in blood culture and measured in conventional method, was also proved in the fully automated system. Further investigation at molecular level is needed to ascertain the reason of this resistance.

As tigecycline has not been used in clinical practices for a long time now, its resistance development remains still unanswered. It is 
suggested that the development of efflux pumps resistant to multiple drugs might be responsible for the resistance ${ }^{33}$.

Several studies executed abroad report that a tigecycline resistance in the rate of $0-0.02$ per cent has been observed in S.aureus isolates. Previous research in our country, on the other hand, found no tigecycline resistance in $S$. aureus isolates ${ }^{1}$.

Another study documented a tigecycline susceptibility of 95.8 per cent in MRSA isolates isolated from the wounds of patients with burns. Besides, it was suggested that tigecycline was proved to be an ineffective agent against $P$. aeruginosa, an important factor of infections in burn centres and was therefore proposed to be used in serious infections only when other options would not come in question 34 .

Another study conducted by Opuş et all. 35 investigated the tigecycline resistance of 85 methicilline-resistant staphylococcus strains, being 35 S.aureus (MRSA) resistant to methicilline and 50 methicilline-resistant coagulase negative Staphylococci (MRCoNS) strains, by means of E-test method. The MIC50 and MIC90 values of tigecycline for 35 MRSAs were found to be $0.094 \mu \mathrm{g} / \mathrm{ml}$ and $0.5 \mu \mathrm{g} / \mathrm{ml}$ respectively, while the values for $50 \mathrm{MRCoNSs}$ were observed to be $0.047 \mu \mathrm{g} / \mathrm{ml}$ for MIC50 and $0.25 \mu \mathrm{g} / \mathrm{ml}$ for MIC90. The study concluded that the whole population of isolates was susceptible to tigecycline.

Aydoğdu et all. ${ }^{2}$ reported that the MRCoNS and MRSA strains provided to them from emergency care units were all susceptible to tigecycline. The results of their measurements to detect the MIC50 and MIC90 values indicated $0.12 \mu \mathrm{g} / \mathrm{ml}$ and $0.25 \mu \mathrm{g} / \mathrm{ml}$ for MRCoNS strains and $0.25 \mu \mathrm{g} / \mathrm{ml}$ and $0.5 \mu \mathrm{g} / \mathrm{ml}$ for MRSAs respectively. As for the values regarding the strains in our study, MIC50 and MIC90 values for MRSAs were found to be $0.12 \mu \mathrm{g} / \mathrm{ml}$ and $0.25 \mu \mathrm{g} / \mathrm{ml}$ and the same values for MRCoNS $0.25 \mu \mathrm{g} / \mathrm{ml}$ and $0.5 \mu \mathrm{g} / \mathrm{ml}$ respectively. Even though all the isolates were found to be susceptible to tigecycline, no significant difference was observed between MRCoNS s and MRSAs in respect of average MIC values.

Although the bio-film or slime produced by coagulase negative staphylococci is an important factor in the pathogenesis of infections, it protects the bacteria from the effects of immune system and those of antibiotics ${ }^{1}$.

Manso et all. ${ }^{36}$ pointed out that even though rifampicin and tigecycline showed high concentration results in respect of minimum bio-film eradication especially in S.epidermidis strains, they were still the most effective antibiotics to eliminate the bio-film. All the MRCoNS strains used in our study were obtained from blood samples. The patient profile in our study consisted of patients hospitalized in the emergency care unit, most of whom used a catheter. In terms of average MIC values of tigecycline, we assume that the difference between MRCoNS and MRSA could be attributed to bio-film production. However further research has to be performed to confirm it.

Ceftaroline fosamil is an intravenous cephalosporin approved for community-onset pneumonia and acute bacterial skin infections. Serum half-life was 2.6 hours, protein binding was $20 \%$, urine excretion was $75 \%$. The dose is given as $600 \mathrm{mg}$ intravenous infusion twice a day ${ }^{37}$.

It is a fact that no research to date has investigated the effectiveness of this new drug, which is not used in clinical practices in Turkey, on the MRSA strains in our country. In this multi-centre study that examined the in-vitro effectiveness of ceftaroline against MRSA strains, however, of 194 MRSA isolates investigated 94.3 per cent were found to be susceptible and 5.7 per cent at medium susceptibility. The rate of isolates observed to be medium-susceptible in the centres involved 
in the study varied between $0-12.5$ per cent. In our study, 30 MRSA strains showed a ceftaroline resistance rate of 36.6 per cent. While in a previous study MIC50 and MIC90 values were documented as $0.5 \mu \mathrm{g} / \mathrm{ml}$ and 1 $\mu \mathrm{g} / \mathrm{ml}$ respectively, the results of our study indicate MIC50 and MIC90 values of $1 \mu \mathrm{g} / \mathrm{ml}$ and $2 \mu \mathrm{g} / \mathrm{ml}$ respectively. We are of the opinion that the high resistance rate we have found in our study can be attributed to the resistant strains in our hospital as the unique centre and to the difference in our research methods. During our study we have found that no previous research has investigated ceftaroline in our country ${ }^{38}$.

MIC value of ceftaroline of 157 out of 409 MRSA strains was measured as 2 in another study. EUCAST evaluation indicates a resistance rate of 38.4 per cent. MIC50 and MIC90 values were found to be $1 \mu \mathrm{g} / \mathrm{mL}$ and $2 \mu \mathrm{g} / \mathrm{mL}$ respectively. We presume that the similarity between MIC50 and MIC90 values we have obtained in our study and those obtained in the study mentioned can be ascribed to the fact that the data obtained in the study reflect the results related to Latin American countries, all of which are developing countries like our country ${ }^{39}$.

\section{CONCLUSION}

Treatment doses under the MIC value of antibiotics is an important factor in the formation of mutant bacteria, but they can lead to failures in a treatment process. In order to keep under control the resistance developed against antibiotics in the treatment of infections associated with MRSAs and MRCoNS $\mathrm{s}$, the clinician should be informed about the MIC values of drugs to work out the most appropriate planning for the treatment.

VISA/hVISA can be taken into consideration in MRSA infections where the treatment fails although susceptible to vancomycin in terms of in-vitro susceptibility, and detailed investigation should be performed in this respect.

Even though ceftaroline is not a drug used in our country, it stood out with a high resistance rate in our study. Such a high value is associated with the intense usage of other $\beta$ lactamase antibiotics. In planning the treatment of infectious diseases, antibiogram results should therefore absolutely be taken into account.

The level of average MIC values of tigecycline in MRCoNS infections must be monitored.

Declaration of Conflicting Interests: The authors declare that they have no conflict of interest.

Financial Disclosure: Supported by DUBAP with project number 13-TF-59

\section{REFERENCES}

1. Sancak B . Staphylococcus aureus and Antibiotic Resistance. Mikrobiyol Bul. 2011; 45: 565-76.

2. Aydogdu S, Karamese M, Altoparlak U. Evaluation of the Activities of Antimicrobial Agents on Multi-drug Resistant Gram Positive Bacteria Isolated from Intensive Care Units. SOJ Microbiol Infect Dis.2014; 2: 1-5.

3. The European Committee on Antimicrbial Susceptibility Testing. Breakpoint tables for interpretation of MICs and zone diameters Version 4, (2014). http://www. eucast. org. Erişim tarihi: 01. 02. 2014.

4. Wootton M, MacGowan A. P, Walsh T. R, Howe R. A. A Multicenter Study Evaluating the Current Strategies for Isolating Staphylococcus aureus Strains with Reduced Susceptibility to Glycopeptides. Journal of Clinical Microbiology. 2007; 45: 329-32.

5. Sancak B. Methicillin and Vancomycin Resistance in Staphylococcus aureus. Hacettepe Tıp Derg. 2007; 38: 127-34.

6. Öksüz L. Gürler N.In Vitro Susceptibility Results of Antibiotics Used in Recent Years for Methicillin Resistant Staphylococcus Strains Isolated from Clinical Samples ANKEM Derg 2009; 23: 71-77.

7. Hal S. J. van, Fowler V. G. Is it time to replace vancomycin in the treatment of methicillin-resistant Staphylococcus aureus infections. Clin Infect Dis. 2013; 56: 1779-88. 
8. Prakash V, Lewis II J. S, Jorgensen J. H. Vancomycin MICs for Methicillin-Resistant Staphylococcus aureus Isolates Differ Based upon the Susceptibility Test Method Used Antimicrob. Agents Chemother. 2008; 52: 4528.

9. Ippolito G, Leone $\mathrm{S}$, Lauria $\mathrm{FN}$, et all. Methicillinresistant Staphylococcus aureus: the superbug. Int J Infect Dis. 2010; 14: 7-11.

10. Korten V., Multi-Drug Resistant Gram Positive Bacteria (MRSA and VRE): Treatment And Control. ANKEM Derg. 2013; 27(Ek 2): 57-62.

11. Doğanay V, Kizirgil A. In Vitro Activity on Gram Positive Cocci of Quinupristin/dalfopristin and Other Eight Antimicrobial Agents. F.Ü. Sağ. Bil. Derg. 2007: 21: 129-32.

12. Yavuz M. T, Behçet M, Öztürk C. E, et all. Susceptibilities of Staphylococcus aureus strains to quinupristin/dalfopristin. Türk Mikrobiyol Cem Derg. 2006; 36: 190-4.

13. Çelik C, Bakıcı M. Z, Gözel M. G, et all. Antimicrobial resistance paternity in Staphylococcus aureus strains isolated from bloodstream infections. Genel Tip Derg. 2013; 23: 109-13.

14. Elsahn AF, Yildiz EH, Jungkind DL, et all. In vitro susceptibility patterns of methicillin-resistant Staphylococcus aureus and coagulase-negative Staphylococcus corneal isolates to antibiotics. Cornea. 2010 Dec; 29: 1470.

15. Türk Dağı H, Arslan U, Tuncer İ. Antibiotic Sensitivity of Staphylococcus aureus Strains Isolated from Blood Cultures. ANKEM Derg. 2011; 25: 84-8.

16. Doğan M, Feyzioğlu B, Baykan M. Change in Antibiotic Resistance of $S$. aureus Strains in the Decade Period. Abant Med J. 2014; 3: 237-41.

17. Yanık K, Yılmaz H, Tanriverdı Caycı Y, et all. Glycopeptides And Linezolıd MIC Changes In Staphylococcus aureus And Coagulase Negative Staphylococcl Isolates From 2008-2011. Acta Medica Mediterranea. 2014; 30: 995.

18. Kuşcu F, Öztürk D.B, Gürbüz Y, et all. Investigation of Decreased Vancomycin Sensitivity in Methicillin Resistant Staphylococci. Mikrobiyol Bul. 2011; 45: 24857.

19. Richter S. S, Diekema D.J, Heilmann K. P, et all. Activities of Vancomycin, Ceftaroline, and Mupirocin against Staphylococcus aureus Isolates Collected in a 2011 National Surveillance Study in the United States. Antimicrobial Agents and Chemotherapy. 2014; 58: 740-5.

20. Celikbilek N, Ozdem B, Gürelik FC, et all. In vitro susceptibility of methicillin-resistant Staphylococcus aureus isolates to vancomycin, teicoplanin, linezolide and daptomycin. Mikrobiyol Bul. 2011; 45: 512-8.
21. Aktaş G, Derbentli Ş. Daptomisinin VRE ve MRSA Suşlarına İn Vitro Etkinliği. Mikrobiyol Bul. 2014; 48: 123-8.

22. Hancı H, Uyanık M. H, Bilici D, et all. Investigation of Daptomycin Activity in Methicillin Resistant Staphylococcus Strains Isolated from Clinical Samples. ANKEM Derg. 2013; 27: 64-9.

23. Sader H. S., Flamm R. K., Jones R. N. Antimicrobial Activity of Ceftaroline Tested against Staphylococci with Reduced Susceptibility to Linezolid, Daptomycin, or Vancomycin from U.S. Hospitals, 2008 to 2011. Antimicrob Agents Chemother. 2013; 57: 3178-81.

24. Werth B. J, Steed M. E, Kaatz G. W, Rybak M. J. Evaluation of Ceftaroline Activity against Heteroresistant Vancomycin-Intermediate Staphylococcus aureus and Vancomycin Intermediate Methicillin-Resistant S. aureus Strains in anIn Vitro Pharmacokinetic/Pharmacodynamic Model: Exploring the "Seesaw Effect". 2013; 57: 2664-8.

25. Kaya S. Treatment of Community-Acquired Methicillin Resistant Staphylococcus aureus Infections. J Med Sci. 2008; 28: 956-61.

26. Adaleti R, Nakipoğlu Y, Ceran N, et all. Prevalence of phenotypic resistance of Staphylococcus aureus isolates to macrolide, lincosamide, streptogramin B, ketolid and linezolid antibiotics in Turkey. Braz J Infect Dis. 2010; 14: 11-4.

27. Khalid A, Umsan J, Faiz U, et all. In-vitro susceptibility of linezolid against methicillin resistant Staphylococcus aureus at a tertiary care hospital in Pakistan. Journal of Microbiology and Infectious Diseases. 2013; 3: 203-6.

28. Al F., D, Akca G, Akyan B, et all. Quinupristin/dalfopristin, Linezolide Susceptibilities and Macrolide-Linkozamide-Streptogramin B Resistance in Methicillin Resistant Staphylococcus aureus Strains. Turkish Journal of Infection. 2008; 22: 153-63.

29. Ağalar C, Göçmen J. S, Kılıç D, et all. Sensitivity to methicillin-resistant staphylococcal strains isolated in a tertiary referral hospital. Journal of Clinical and Experimental Investigations. 2012; 3: 71-4.

30. Efe Ş, Sınırtaş M, Özakın C. In Vitro Linezolid Sensitivity of Methicillin Resistant Staphylococcus aureus and Vancomycin Resistant Enterococcus Strains. Mikrobiyol Bul. 2009; 43: 639-43.

31. Kali A, Stephen S, Umadevi S, Kumar S. Detection of quinupristin/dalfopristin resistance in methicillineresistant Staphylococcus aureus in South İndia. İndian J Pathol Microbiol. 2013; 5: 73-4.

32. Ulusoy S. Streptograminler (Kinupristin/dalfopristin). ANKEM Derg. 2004; 18 (Ek 2):174-7.

33. Çalık N, Akova M. Tigesiklin. ANKEM Derg. 2007; 21(Ek 2): 29-33. 
34. Zorgani A, Elahmer O, Ziglam H, Ghenghesh K. S. Invitro activity of tigecycline against methicillin-resistant Staphylococcus aureus Isolated from wounds of burn patients in Tripoli-Libya. Journal of Microbiology and Infectious Diseases (JIMD). 2012; 2: 109-12.

35. Opuş A, Keşli R, Kurtoğlu M. G, Güzelant A, Uysal E. B. Investigation of tigecycline activity in methicillinresistant staphylococcal strains. Turk Hij Den Biyol Derg: 2012; 69: 121-6.

36. Manso D. M, Prado D. del, Perez A. O, et all. In vitro susceptibility to antibiotics of staphylococci in biofilms isolated from orthopaedic infections. International Journal of Antimicrobial Agents. 2013; 521-3.
37. Erdinç F.Ş. Sefalotinden, seftobiprole, seftaroline. Ankem Derg 2013; 27 (Ek 2):124-6.

38. Mengeloğlu F. Z, Taş T, Koçoğlu E, et all. In Vitro Activity of MRSA Isolates of Ceftarolin: A Multicenter Study. Mikrobiyol Bul. 2013; 47: 677-83.

39. Flamm R. K, Sader H. S, Jones R. N. Ceftaroline activity tested against contemporary Latin American bacterial pathogens 2011. Braz j infect dis. 2014 4; 18: 187-95. 